\title{
Interaksi dan Hubungan Kausalitas antara Net Foreign Flow dan Return Saham Syariah (Studi Empiris Saham Syariah Jakarta Islamic Index Periode 2012-2018)
}

\author{
Zulfan $^{1)}$, Rizqi Umar Al Hashfi'), William Wendy Ary ${ }^{3 *}$ \\ ${ }^{1)}$ Magister Sains Manajemen, Fakultas Ekonomika dan Bisnis, Universitas Gadjah Mada \\ ${ }^{2)}$ Centre for Research in Islamic Economics and Business, Fakultas Ekonomika dan Bisnis, \\ Universitas Gadjah Mada \\ ${ }^{3 *}$ Program Studi Manajemen, Institut Shanti Bhuana \\ E-mail: william.wendy@shantibhuana.ac.id
}

\begin{abstract}
ABSTRAK
Dengan adanya globalisasi pasar modal, investor dapat melakukan investasi di berbagai negara sesuai dengan potensi keuntungan yang diharapkan masing-masing investor. Penilaian investor asing terhadap suatu pasar saham dapat berubah-ubah sesuai dengan informasi yang diperoleh. Penelitian ini berfokus menguji hubungan antara aliran modal asing dan return saham syariah pada Jakarta Islamic Index. Jenis data yang digunakan adalah panel. Sampel terdiri dari saham-saham yang secara konsisten terdaftar pada JII selama tahun 2012 - 2018. Kesimpulan yang dapat diambil dari penelitian "net foreign flow dan interaksinya dengan return saham di indeks JII" menunjukkan aliran modal asing berpengaruh signifikan positif terhadap return saham. Hal ini disebabkan oleh optimisme investor asing terhadap perekonomian dan prospek pasar saham. Realisasi return yang sesuai diharapkan diterima oleh investor asing akan membuat peningkatan aliran modal asing yang masuk ke indeks pasar saham JII. Investor asing dalam berinvestasi menggunakan strategi momentum ataupun feedback trading positif.
\end{abstract}

Kata kunci: Arus Modal Asing, Pasar Modal Syariah, Jakarta Islamic Index, Return Saham

\begin{abstract}
With the globalization of the capital market, investors can invest in various countries in accordance with the potential benefits expected by each investor. The foreign investor's assessment of a stock market may change according to the information obtained. This study focuses on examining the relationship between foreign capital flows and Islamic stock returns on the Jakarta Islamic Index. The type of data used is the panel. The sample consisted of stocks that were consistently listed in JII during 2012 - 2018. The conclusions that can be drawn from the research "net foreign flow and their interaction with stock returns on the JII index" show that foreign capital flows have a significant positive effect on stock returns. This is due to the optimism of foreign investors on the economy and the prospects for the stock market. The realization of the appropriate return that is expected to be received by foreign investors will increase the flow of foreign capital into the JII stock market index. In investing, foreign investors use momentum strategies or positive trading feedback.
\end{abstract}

Keyword: Net Foreign Flow, Sharia Stock Market, Jakarta Islamic Index, Stock Return 


\section{PENDAHULUAN}

Arus globalisasi memberikan dampak besar dalam perkembangan pasar modal dan juga berdampak pada keputusan investasi investor asing dari negara maju ke dalam pasar modal negara berkembang. Globalisasi pasar modal telah menjadikan sistem ekonomi antar negara semakin terintegrasi dari ekonomi nasional menuju ke dalam sebuah sistem ekonomi global. Dengan adanya globalisasi pasar modal, investor dapat melakukan investasi di berbagai negara sesuai dengan potensi keuntungan yang diharapkan masing-masing investor.

Penilaian investor asing terhadap suatu pasar saham dapat berubah-ubah sesuai dengan informasi yang diperoleh. Investor asing akan cenderung melakukan pembelian saham dengan jumlah besar ketika informasi yang diperoleh berupa good news dan begitu sebaliknya investor asing cenderung melakukan penjualan saham ketika informasi yang diperoleh berupa bad news.

Berdasarkan data yang tercatat CBEST pada bulan Juli 2017, total aset saham di Bursa Efek Indonesia masih didominasi oleh investor asing dengan persentase kepemilikan sebesar 53\%. Sedangkan persentase kepemilikan saham investor lokal adalah sebesar 47\%. Dengan demikian, investor asing memandang pasar saham Indonesia mempunyai peluang keuntungan yang besar di masa depan, sehingga hal ini merupakan suatu good news. Investor asing dipandang mempunyai dana investasi yang besar, sehingga investor asing dapat berperan sebagai pemimpin pasar modal Indonesia karena mampu melakukan transaksi perdagangan saham dalam nominal dan volume yang besar (KSEI press release, 2017).

Namun di sisi lain, kehadiran investor asing yang berlebihan dapat menimbulkan dampak negatif jika investor asing telah mendominasi suatu pasar modal, sehingga menyebabkan ketergantungan terhadap aliran dana investor asing. Ketergantungan pada aliran dana asing dapat menimbulkan ketidakstabilan suatu pasar modal sehingga rentan terjadinya risiko global. Sevil (2012) menunjukkan bahwa investor asing dapat menyebabkan noisy trading yang menyiratkan alasan untuk membeli atau menjual sekuritas yang dihasilkan dari ekspektasi dan sentimen tersebut.

Aliran modal investasi asing ini mempunyai karakterisitk hot money, yaitu masuknya net foreign flow dalam jumlah yang cukup besar dapat membuat harga saham yang sedang naik menjadi semakin tinggi. Namun sebaliknya, keluarnya net foreign flow mengakibatkan harga saham yang sedang turun menjadi semakin rendah jika jumlah transaksi pejualan lebih besar 
dibandingkan transaksi pembelian. Globalisasi pasar modal membuat investor asing leluasa untuk melakukan investasi atau menarik investasinya dengan tiba-tiba. Sebagaimana yang telah dijelaskan sebelumnya bahwa tingkat kepercayaan investor dapat meningkatkan aliran modal tersebut dapat dengan mudah mengalir ke dalam suatu pasar saham dan juga keluar secara tibatiba dalam jumlah yang besar. Transaksi perdagangan dan jumlah net foreign flow dapat diketahui dengan mengamati jumlah volume bersih dan nilai bersih perdagangan oleh investor asing, pada umumnya di Indonesia dikenal dengan sebutan net foreign buy dan net foreign sell. Net foreign sell terjadi ketika investor asing menarik dananya atau dengan kata lain melakukan penjualan saham dengan jumlah yang lebih besar dibandingkan jumlah pembeliannya, sehingga dapat menyebabkan harga saham bergerak negatif dan membuat return saham turun. Sedangkan net foreign buy adalah apabila investor asing melakukan pembelian dengan jumlah yang lebih besar dibandingkan jumlah penjualan, maka harga saham akan bergerak positif dan meningkatkan return saham.

Berdasarkan penjelasan tersebut, penulis berpendapat bahwa aliran investor asing (foreign flow) baik itu net foreign buy atau net foreign sell memiliki kecenderungan untuk mempengaruhi pergerakan harga dan return saham. Selain itu penulis juga menduga bahwa terdapat hubungan kausalitas antara net foreign flow dengan tingkat return saham (lihat Tabel 1).

Tabel 1. Rekapitulasi Nilai Perdagangan Saham di Bursa Efek Indonesia Berdasarkan Tipe Investor Tahun 2015

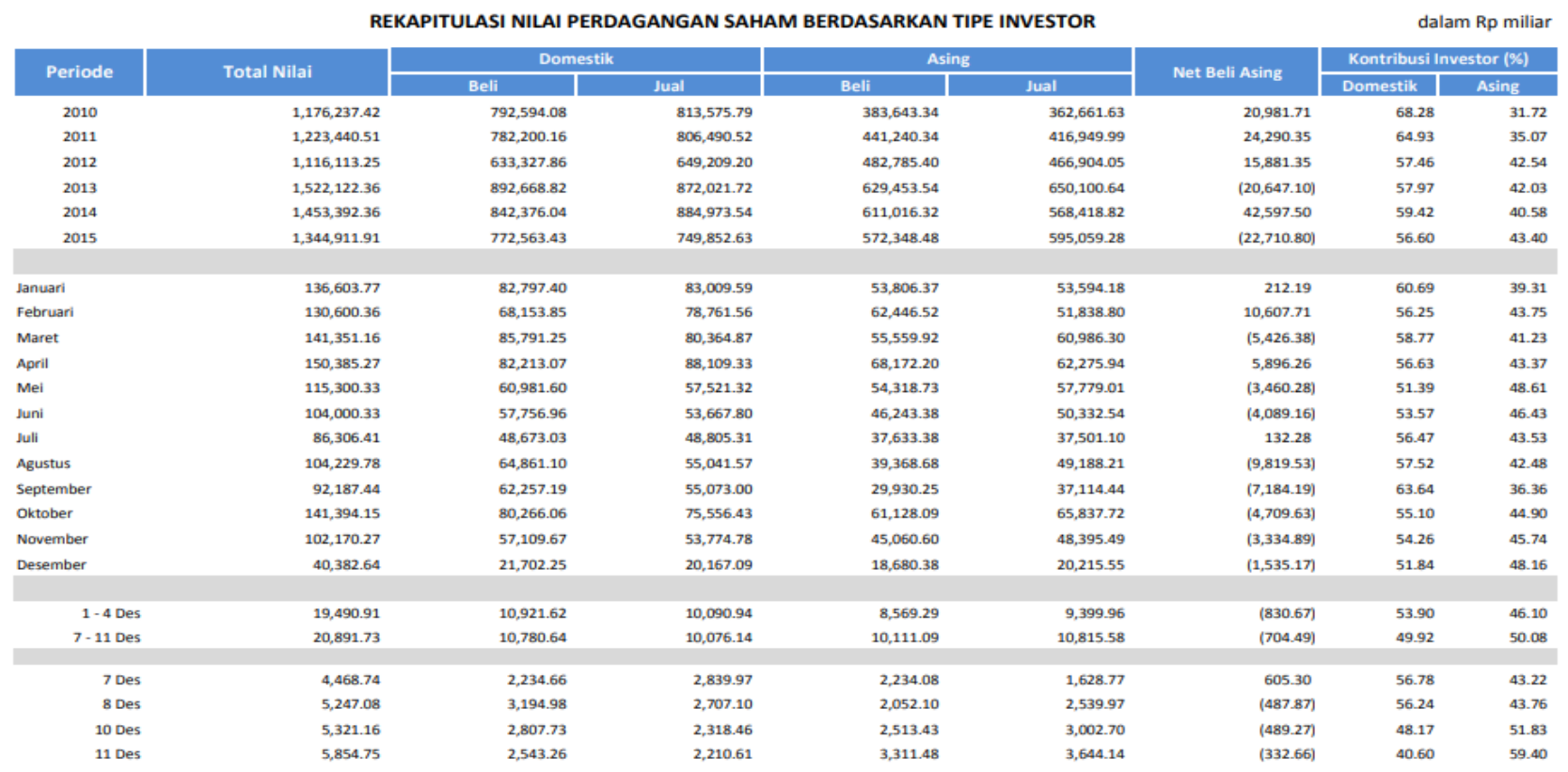


Berdasarkan Gambar 1, dapat dilihat bahwa sejalan dengan tren IHSG, Perubahan harga saham Jakarta Islamic Index dari tahun 2012 hingga tahun 2018 juga memiliki tren naik yang mengindikasikan minat masyarakat untuk berinvestasi pada bursa saham syariah di Indonesia juga mengalami peningkatan. Namun pada tahun 2015 Index saham syariah, khususnya JII mengalami down trend sepanjang tahun.

200

180

160

140

120

100

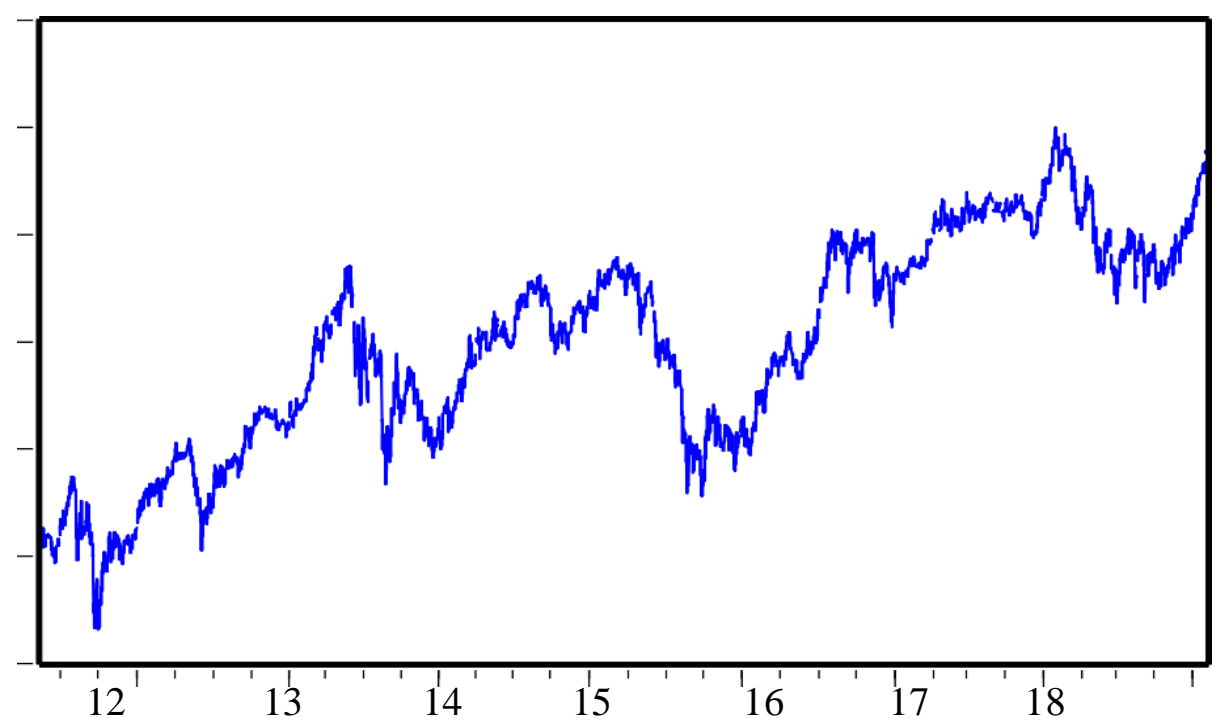

Gambar 1. Indeks Harga Saham Gabungan 2012-2018

Sumber: www.idx.co.id (2018)

Memasuki tahun 2016, investor asing mulai melakukan akumulasi saham-saham yang di Bursa Efek Indonesia. Tercatat bahwa pada Januari 2016 JII berada pada range level 590-620, kemudian terjadi kenaikan dan rebound menuju pada range 650-750 dalam bulan Maret sampai dengan Agustus. Namun sejak bulan Desember, investor asing kembali melakukan net sell di Bursa Efek Indonesia yang membuat harga saham-saham syariah yang tergabung dalam Jakarta Islamic Index kembali bergerak negatif di periode. Tabel 2 berikut ini menunjukkan jumlah net foreign flow pada tahun 2016. Pada awal tahun 2016, investor asing melakukan net buy sebesar Rp 16,169 triliun, sehingga membuat kinerja saham dan juga JII bergerak positif yang pada akhirnya mengalami kenaikan di awal tahun 2016. 
Tabel 2. Rekapitulasi Nilai Perdagangan Saham di Bursa Efek Indonesia Berdasarkan Tipe Investor Tahun 2016

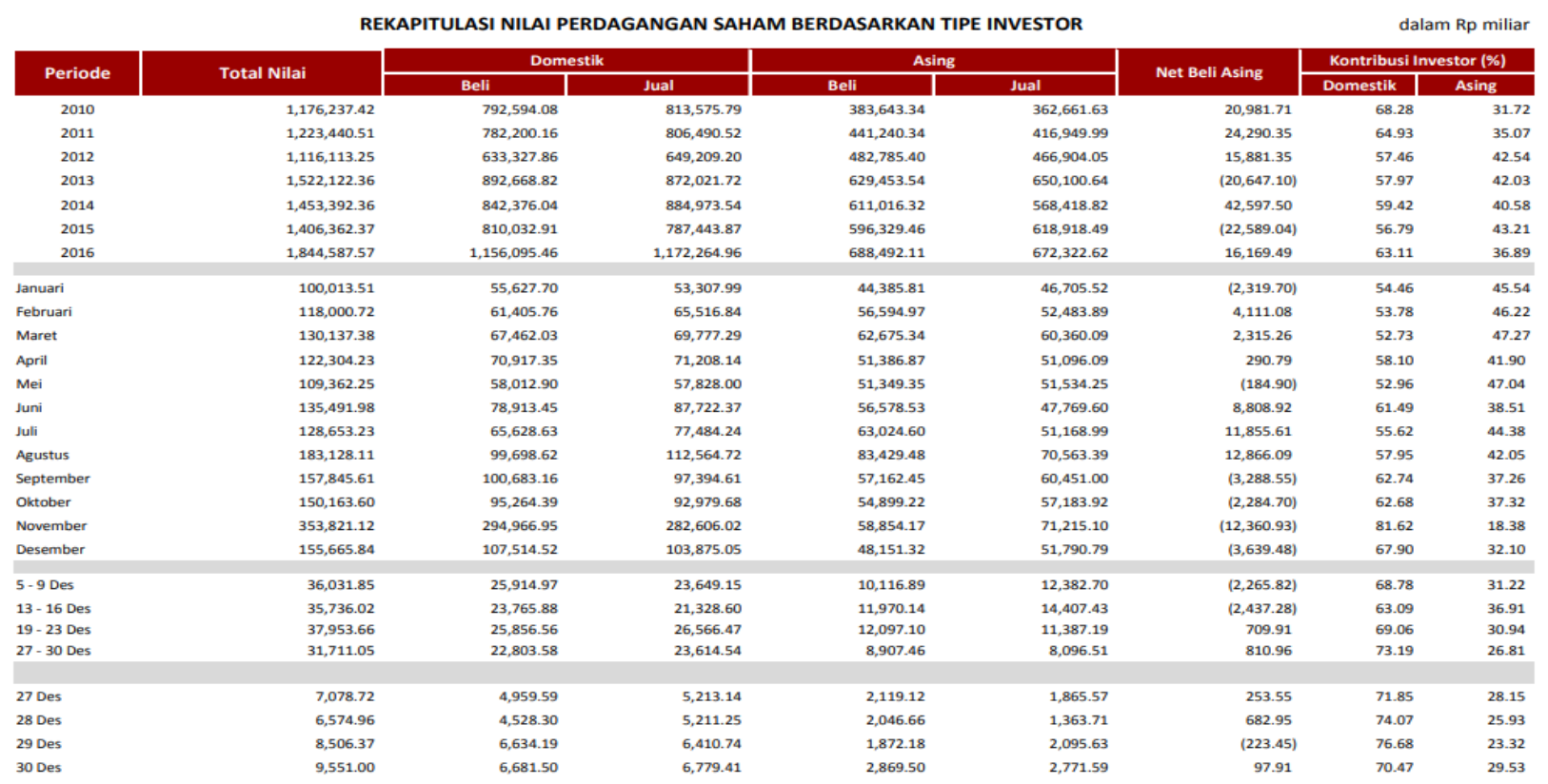

Sumber: Otoritas Jasa Keuangan Indonesia, 2018

Secara teoritis terdapat beberapa penelitian yang membuktikan hubungan antara antara return saham dengan aliran investasi asing. Nisa (2019) meneliti tentang hubungan antara kepemilikan institusional asing terhadap votalitas harga saham dengan pendapatan kumulatif sebagai proksinya, hasil penelitiannya menunjukkan bawah Kepemilikan institusional asing secara simultan dapat mempengaruhi volatilitas rasio harga saham. Nyang'oro (2013) menjelaskan dalam penelitian jika Jumlah transaksi investor asing dapat mempengaruhi pergerakan harga saham dan performa dari pasar saham. Kemudian, penelitian yang dilakukan oleh Purwaningsari (2012) membuktikan bahwa earning volatility memiliki pengaruh yang signifikan terhadap return saham. Kemudian, penelitian yang dilakukan oleh Nurmalasarie (2015) menunjukkan bahwa terdapat pengaruh yang positif antara net foreign buy dan net foreign sell terhadap return saham perusahaan yang bergabung dalam indeks LQ45

Dalam penelitian yang dilakukan oleh Ramdani (2019) menjelaskan bahwa foreign investors berwenang mengakuisisi seluruh saham perusahaan di Indonesia tanpa batasan kepemilikan investor asing di Indonesia, sehingga investor asing dan investor domestik dapat bergerak bebas dan menjelaskan bahwa investor asing merupakan trader yang handal. Hal tersebut dikarenakan investor asing memiliki keuntungan informasi kumulatif dari investor lokal, karena itu akan mengarah ke hubungan positif antara arus asing bersih dan pengembalian saham 
domestik (Ulku, 2015). Realisasi return saham di masa lalu dipergunakan oleh investor asing untuk memprediksikan harga saham di masa yang akan datang (Froot et al., 2000). Dengan demikian, masuknya aliran modal asing pada suatu pasar saham juga dapat dipengaruhi oleh return saham tersebut pada masa lalu. Salah satu dasar teori yang dapat dijadikan sebagai referensi untuk fenomena di atas adalah teori feedback trading (Clark dan Berko, 1997).

Dalam teori feedback trading terdapat dua arah pola, yaitu positive feedback trading dan negative feedback trading. Positive feedback trading adalah pola perilaku investasi yang menyebabkan investor untuk menjual ketika pasar menurun dan membeli ketika naik atau dengan kata lain investor melakukan transaksi sesuai dengan arah pergerakan pasar saham. Positive feedback trading merupakan alasan mengapa penurunan return pasar dapat menyebabkan penurunan yang lebih lanjut dan juga menyebabkan peningkatan harga dan return lebih lanjut. Hal ini juga merupakan sumber terjadinya volatilitas pasar. Ketika siklus Positive feedback trading berlanjut terlalu lama, maka akan dapat menciptakan gelembung aset atau jatuhnya harga pasar.

Selajutnya, pola perilaku investor yang menggunakan strategi negative feedback trading akan melakukan transaksi beli ketika harga saham menurun dan melakukan transaksi jual ketika harga saham naik. Pola negative feedback trading merupakan kebalikan dari apa yang kebanyakan orang lakukan. Negative feedback trading membantu membuat pasar menjadi lebih tidak stabil, sedangkan positive feedback trading membuat mentalitas kawanan investor mendorong harga tinggi menjadi lebih tinggi dan harga rendah menajdi lebih rendah.

Penelitian lain yang berkaitan dengan hal tersebut juga dilakukan oleh tim peneliti dari Bapepam LK pada tahun 2008 (sekarang disebut Otoritas Jasa Keuangan), penelitian tersebut menunjukkan bahwa pergerakan Indeks Harga Saham Gabungan mempengaruhi aliran modal asing yang masuk ke pasar modal di Indonesia secara signifikan. Ulku (2015) memberikan wawasan baru tentang transaksi saham oleh investor asing dengan menunjukkan informasi global adalah penggerak net foreign flow dan feedback trading investor asing berhubungan dengan tingkat return saham dan volatilitas harga saham domestik.

Namun, tingkat return saham tidak hanya dipengaruhi oleh aliran modal dan transaksi investor asing saja. Terdapat beberapa faktor lain yang dapat mempengaruhi naik dan turunnya tingkat return saham dan juga bisa mempengaruhi minat investor untuk menginvestasikan modalnya dipasar saham. Menurut Brigham dan Houston (2001), terdapat dua faktor yang 
mempengaruhi tingkat return dan resiko investasi saham. Pertama, faktor internal perusahaan seperti kualitas dan reputasi manajemennya, struktur permodalannya, struktur hutang perusahaan, laba perusahaan dan sebagainya. Kedua, yaitu faktor eksternal atau sering disebut juga sebagai faktor makroekonomi, misalnya pengaruh kebijakan moneter dan kebijakan fiskal, inflasi, nilai tukar, tingkat suku bunga, perkembangan sektor industrinya, dan sebagainya.

Variabel makroekonomi menjadi salah satu faktor yang dapat memberikan pengaruh serta korelasi yang kuat terhadap return investasi saham. Dengan demikian penulis mencoba memasukkan faktor makroekonomi sebagai variabel kontrol dalam penelitian ini. Adapun proxy untuk faktor makroekonomi tersebut adalah indeks produksi industri, perubahan kurs (nilai tukar mata uang), inflasi dan tingkat suku bunga/ tingkat bunga bebas resiko, serta index volatility.

Pal dan Ruhee (2011) menemukan bahwa terdapat hubungan ko-integrasi antara variabel makroekonomi dan indeks saham India yang mengindikasikan adanya hubungan investasi saham dalam periode jangka panjang. Hasil temuan mereka menunjukkan bahwa laju inflasi memiliki dampak yang signifikan pada BSE Sensex Index dan S\&P CNX Nifty. Disisi lain, suku bunga memiliki dampak yang signifikan pada S\&P CNX Nifty saja. Namun, dalam kasus kurs mata uang asing, dampak signifikan hanya terlihat pada BSE Sensex Index. Rjoub et al. (2009) juga menunjukkan adanya hubungan yang signifikan antara return saham dengan variabel makroekonomi yang diuji dalam penelitian tersebut; yaitu, inflasi yang tidak diantisipasi, suku bunga, dan uang beredar memiliki efek yang signifikan dalam menjelaskan return pasar saham di berbagai portofolio.

Sementara itu, perubahan kurs rupiah terhadap dolar berdampak pada perubahan laba rugi perusahaan terutama bagi perusahaan yang menggunakan dollar dan berbagai jenis mata uang dalam kegiatan bisnisnya. Dengan adanya perubahan nilai tukar rupiah terhadap dolar maka jumlah penerimaan perusahaan dalam bentuk mata uang rupiah pun akan ikut mengalami perubahan, baik itu perubahan dalam bentuk positif maupun perubahan dalam bentuk negatif.

Beberapa hasil penelitian menemukan bahwa volatilitas dapat mempengaruhi biaya modal perusahaan dan return saham (Minton dan Schrand, 1999), (Bekaert dan Wu, 2000), dan (Botosan dan Plumlee, 2002). Oleh karena itu, memahami bagaimana volatilitas nilai tukar mempengaruhi volatilitas harga saham juga penting untuk pengambilan keputusan investasi. Beberapa penelitian yang serupa juga telah menunjukkan hubungan signifikan antara volatilitas nilai tukar dan return saham (Lima, 2014) dan (Baia dan Koong, 2018). 
Berdasarkan beberapa penelitian terdahulu yang telah dibahas di atas, penulis melihat bahwa penelitian yang membahas tentang transaksi perdagangan saham oleh investor asing serta pengaruhnya terhadap return saham di Bursa Efek Indonesia masih terbatas dan belum ada yang melibatkan saham syariah secara khusus dalam topik penelitian ini. Padahal, beberapa penelitian terdahulu menunjukkan bahwa investor asing ternyata memiliki ketertarikan untuk menginvestasikan modal yang dimilikinya pada saham-saham syariah. Abbes dan Trichilli (2015), studi empiris di masa lalu menunjukkan bahwa pasar keuangan syariah memiliki kinerja yang lebih baik daripada pasar keuangan konvensional pada saat krisis keuangan. Hal ini dapat dijelaskan oleh prinsip dan karakteristik pasar modal syariah itu sendiri, seperti; pelarangan bunga, perjudian/spekulasi dan ketidakpastian yang berlebihan. Sehingga pasar saham syariah dianggap sebagai sebuah investasi yang etik dan bernorma (Alam et al. 2016). Oleh karena itu, pasar saham syariah menyediakan alternatif sebagai sebuah bisnis model yang baru, lebih aman dan memungkinkan peluang keuntungan melalui diversifikasi terutama selama pasar saham sedang dalam kondisi downtrend. Al-Awadhi dan Dempsey (2017) juga menyebutkan bahwa pasar saham syariah lebih liquid dibandingkan dengan pasar saham konvensional sehingga investor terhindar dari risiko likuiditas.

Di Indonesia, terdapat beberapa kriteria dalam pemilihan saham syariah, misalnya debt to equity yang berbasis bunga tidak boleh melebihi 45\%. Selain itu, Otoritas Jasa Keuangan juga melakukan evaluasi pemelihan saham syariah setiap enam bulan, yaitu pada bulan Januari dan Juli pada periode tahun tersebut. Sehingga denga hal ini saham syariah, JII dalam hal ini dianggap sebagai saham pilihan terbaik dan beberapa di antaranya juga termasuk dalam saham LQ45.

Pada akhirnya, penulis ingin menggarisbawahi kembali bahwa fokus dalam penelitian ini adalah untuk meneliti tentang interaksi antara arus modal investor asing bersih (net foreign flow) yang dilihat melalui jumlah volume bersih transaksi dengan return saham-saham syariah yang tergabung dalam Jakarta Islamic Index dengan memasukkan variabel makroekonomi sebagai variabel kontrol penelitian. Kemudian penelitian ini juga mencoba untuk melihat hubungan kausalitas antara net foreign flow dan return saham JII. 


\section{METODE PENELITIAN}

Penelitian ini fokus menguji hubungan antara aliran modal asing dan return saham syariah pada Jakarta Islamic Index. Jenis data yang digunakan adalah panel. Sampel terdiri dari sahamsaham yang secara konsisten terdaftar pada JII selama tahun 2012 - 2018. Saham-saham yang dianalisis adalah saham AALI, ADRO, AKRA, ASII, BSDE, ICBP, INDF, KLBF, LPKR, LSIP, PGAS, SMGR, SMRA, TLKM, UNTR, UNVR dan WIKA. Pada analisis time series, pengujian kausalitas menggunakan vector autoregressive (VAR). Karena penelitian ini menggunakan data panel dengan dimensi waktu yang cukup panjang, penelitian ini menggunakan analisis panel vector autoregressive (PVAR). Seperti halnya VAR pada time series, aplikasi pada data panel memiliki kesamaan yakni pemodelan tidak didasarkan pada teori. PVAR hanya mengakomodasi hubungan pada tingkat lag namun tidak pada waktu yang sama (contemporaneous). Namun PVAR digunakan untuk pengujian hubungan kausalitas pada penelitian sebelumnya (Lin et.al., 2019). Untuk menguji hubungan pada waktu yang sama, penelitian ini menggunakan two-stages least square (Lee et.al., 2015). Variabel-variabel yang diuji pada penelitian tersaji pada tabel berikut:

Tabel 3. Variabel dan Definisi Operasional

\begin{tabular}{|c|c|c|c|}
\hline Variabel & Rumus & Keterangan Rumus & Definisi Operasional \\
\hline $\begin{array}{l}\text { Return } \\
\text { bulanan } \\
\text { saham } \\
\text { perusahaan }\end{array}$ & $R E T_{i t}=\ln \left(\frac{P_{i t}}{P_{i t-1}}\right)$ & $\begin{aligned} \mathrm{r}_{\mathrm{it}}= & \text { return } \text { saham } \mathrm{i} \text { pada } \\
& \text { akhir bulan } \mathrm{t} \\
\mathrm{P}_{\mathrm{it}}= & \text { close price saham } \mathrm{i} \\
& \text { pada akhir bulan } \mathrm{t} \\
\mathrm{P}_{\mathrm{it}-1}= & \text { close price } \text { saham } \mathrm{i} \\
& \text { pada akhir bulan } \mathrm{t}-1\end{aligned}$ & $\begin{array}{l}\text { selisih antara jumlah yang } \\
\text { diterima dan jumlah yang } \\
\text { diinvestasikan oleh } \\
\text { investor. }\end{array}$ \\
\hline $\begin{array}{l}\text { Net } \\
\text { Foreign } \\
\text { Flow }\end{array}$ & $N F_{i t}=\frac{N F B_{i t}-N F S_{i t}}{V O L_{i t}}$ & $\begin{array}{ll}\text { NF } & =\text { Net foreign flow } \\
& \text { saham i pada akhir } \\
& \text { bulan t } \\
\text { NFB } & =\text { Net foreign buy } \\
& \text { saham i pada akhir } \\
& \text { bulan t } \\
\text { NFS } & =\text { Net foreign sell } \\
& \text { saham i pada akhir } \\
& \text { bulan t } \\
\text { VOL } & =\text { total volume transaksi } \\
& \text { saham i pada akhir } \\
& \text { bulan t }\end{array}$ & $\begin{array}{l}\text { total transaksi pembelian } \\
\text { oleh investor asing (foreign } \\
\text { buy) dikurangi dengan total } \\
\text { penjualan oleh investor asing } \\
\text { (foreign sell) }\end{array}$ \\
\hline $\begin{array}{l}\text { Stock } \\
\text { turnover }\end{array}$ & $T U R N_{i t}=\frac{T R A V O L_{i t}}{M C A P_{i t}}$ & $\begin{aligned} \text { TURN }_{\text {it }} & =\text { stock turnover } \\
& \text { saham i pada } \\
& \text { akhir bulan ke-t } \\
\text { TRAVOL }_{\text {it }} & =\text { rata-rata }\end{aligned}$ & $\begin{array}{l}\text { salah satu ukuran likuiditas } \\
\text { saham }\end{array}$ \\
\hline
\end{tabular}




\begin{tabular}{|c|c|c|c|}
\hline Variabel & Rumus & Keterangan Rumus & Definisi Operasional \\
\hline & & $\begin{array}{ll} & \text { volume } \\
& \text { perdagangan } \\
& \text { pada saham i } \\
& \text { selama periode } \\
& \text { bulan t } \\
\text { MCAP }_{\text {it }} & =\text { kapitalisasi } \\
& \text { pasar saham i } \\
& \text { pada akhir } \\
& \text { bulan ke-t }\end{array}$ & \\
\hline $\begin{array}{l}\text { Return } \\
\text { pasar }\end{array}$ & $\begin{array}{l}\text { Sama dengan rumus } \\
\text { return saham }\end{array}$ & $\begin{array}{l}\text { Sama dengan rumus return } \\
\text { saham }\end{array}$ & $\begin{array}{l}\text { informasi yang dapat } \\
\text { mencerminkan iklim } \\
\text { investasi yakni ekonomi } \\
\text { makro dan siklus bisnis. }\end{array}$ \\
\hline $\begin{array}{l}\text { Indeks } \\
\text { produksi } \\
\text { industri }\end{array}$ & $R I P I_{t}=\frac{I P I_{t}-I P I_{t-1}}{I P I_{t-1}}$ & $\begin{array}{ll}\text { RIPI } & \begin{array}{l}\text { p persentase perubahan } \\
\text { indeks }\end{array} \\
\text { IPI }_{t} & =\text { angka IPI pada } \\
& \text { periode } \mathrm{t} \\
\mathrm{IPI}_{\mathrm{t}-1} & =\text { angka IPI pada } \\
& \text { periode } \mathrm{t}-1\end{array}$ & $\begin{array}{l}\text { proksi siklus bisnis pada } \\
\text { suatu negara }\end{array}$ \\
\hline $\begin{array}{l}\text { Volatility } \\
\text { Index } \\
\text { (VIX) }\end{array}$ & - & - & $\begin{array}{l}\text { Proksi sentimen global } \\
\text { terhadap pasar keuangan }\end{array}$ \\
\hline $\begin{array}{l}\text { Nilai } \\
\text { Tukar } \\
\text { Mata Uang } \\
\text { (Kurs IDR } \\
\text { terhadap } \\
\text { US\$) }\end{array}$ & $K U R S=\frac{P_{U S \$, t}-P_{U S \$, t-1}}{P_{U S \$, t-1}}$ & $\begin{array}{l}\text { KURS }=\text { persentase perubahan } \\
\text { nilai kurs } \\
\mathrm{P}_{\mathrm{USs}, \mathrm{t}} \quad=\text { angka kurs pada } \\
\text { periode } \mathrm{t} \\
\mathrm{P}_{\mathrm{US}, \mathrm{t}-1}=\text { angka kurs pada } \\
\text { periode } \mathrm{t}-1\end{array}$ & $\begin{array}{l}\text { faktor risiko yang perlu } \\
\text { diperhatikan untuk } \\
\text { membentuk portofolio } \\
\text { yang efisien }\end{array}$ \\
\hline $\begin{array}{l}\text { Tingkat } \\
\text { inflasi } \\
\text { (INF) }\end{array}$ & $I N F=\frac{I H K_{t}-I H K_{t-1}}{I H K_{t-1}}$ & $\begin{array}{l}\text { INF }=\text { persentase perubahan } \\
\text { nilai inflasi } \\
\mathrm{IHK}_{\mathrm{t}}=\text { angka inflasi pada } \\
\text { periode } \mathrm{t} \\
\mathrm{IHK}_{\mathrm{t}-1}=\text { angka inflasi pada } \\
\text { periode } \mathrm{t}-1\end{array}$ & $\begin{array}{l}\text { peningkatan harga secara } \\
\text { umum }\end{array}$ \\
\hline $\begin{array}{l}\text { Tingkat } \\
\text { bunga } \\
\text { bebas } \\
\text { risiko } \\
\text { (RRF) }\end{array}$ & - & $\begin{array}{l}\text { tingkat bunga bank } \\
\text { Indonesia }\end{array}$ & $\begin{array}{l}\text { merupakan tingkat } \\
\text { expected return dari aset } \\
\text { yang memiliki tingkat } \\
\text { risiko paling rendah }\end{array}$ \\
\hline
\end{tabular}

Sumber: Data diolah, 2020

\section{HASIL DAN PEMBAHASAN}

Penelitian ini menguji apakah terdapat hubungan kausalitas antara transaksi investor asing dan return saham syariah Jakarta Islamic Index (JII). Berdasarkan telaah pustaka dari penelitian 
sebelumnya, transaksi investor asing mempengaruhi return saham. Penelitian lain juga menyimpulkan hubungan terbalik yakni return saham mempengaruhi transaksi investor asing. Berdasarkan studi penelitian sebelumnya peneliti menduga terdapat hubungan kausalitas antara transaksi investor asing dan return saham syariah.

\section{Analisis Deskriptif}

Tabel 4 menyajikan statistik deskriptif dan matriks korelasi secara keseluruhan dari variabel endogen (RET dan NETFOR) dan eksogen (ISSI, TURN, dan IPI). Panel A memberikan informasi statistik deskriptif mencakup rerata, standar deviasi, uji normalitas, dan uji stasioneritas sedangkan Panel B menyajikan matriks korelasi. Grafik 1 menunjukkan pergerakan rata-rata return dan net foreign gabungan dari 17 saham tersebut bulanan dari tahun 2012-2018.

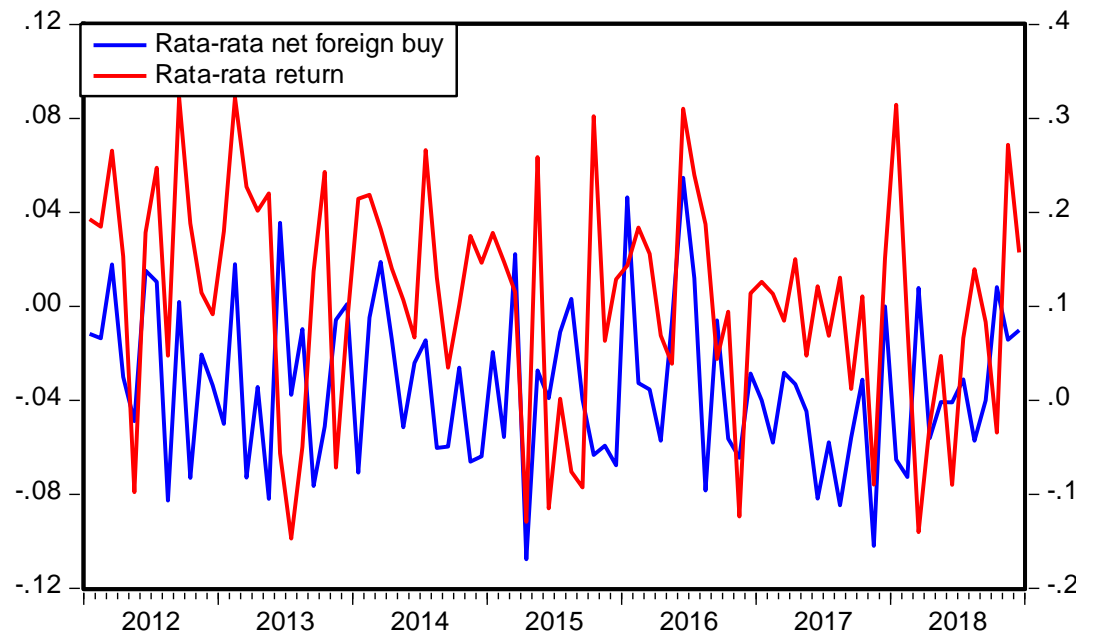

Grafik 1. Rata-rata Net Foreign Flow dan Return Saham Bulanan dari Periode 2012-2018

Tabel 4. Statistik Deskriptif

\begin{tabular}{|c|c|c|c|c|c|c|c|}
\hline & Obs & Rerata & Stdev & Min. & Maks. & S-W & ADF \\
\hline \multicolumn{8}{|c|}{ Panel A: Statistik deskriptif informasi pasar dan fundamental } \\
\hline RET & 1260 & 0,003 & 0,091 & $-0,369$ & 0,400 & $5,912^{* *}$ & $607,34^{* *}$ \\
\hline NETFOR & 1260 & 0,016 & 0,208 & $-0,325$ & 0,349 & $7,717^{* *}$ & $590,88^{* *}$ \\
\hline ISSI & 1260 & 0,004 & 0,034 & -0.088 & 0.066 & $9,266^{* *}$ & $502,69^{* *}$ \\
\hline TURN & 1260 & 28,756 & 23,093 & 2,485 & 191,951 & $12,684^{* *}$ & $307,88^{* * *}$ \\
\hline \multicolumn{8}{|c|}{ Panel B: Statistik deskriptif informasi ekonomi makro } \\
\hline RIPI & 1260 & 0,004 & 0,035 & $-0,134$ & 0,142 & $11,010^{* *}$ & $1081,3^{\text {** }}$ \\
\hline VIX & 1260 & 2,709 & 0,229 & 2,252 & 3,347 & $6,963^{* *}$ & $198.09^{\text {*** }}$ \\
\hline KURS & 1260 & 0,005 & 0,022 & $-0,068$ & 0,061 & $9,963^{* *}$ & $556.80^{* *}$ \\
\hline INF & 1260 & 0,001 & 0,032 & $-0,280$ & 0,045 & $16,085^{* *}$ & $564.14^{\text {** }}$ \\
\hline RRF & 1260 & 0,005 & 0,001 & 0,004 & 0,006 & $9,420^{* *}$ & $65.285^{\text {** }}$ \\
\hline
\end{tabular}

Tabel ini menunjukkan statistik deskriptif. Panel A memuat informasi pasar dan fundamental yakni return saham (RET); rasio net foreign terhadap total volume (NETFOR); return Indeks Harga Saham Gabungan (IHSG); stock turnover (TURN); rasio market to book (MTB). Panel B berisi informasi ekonomi makro yakni pertumbuhan industrial production index (RIPI); CBOE Volatility Index (VIX); perubahan kurs Rp/\$ US (KURS); inflasi (INF) dan; tingkat bunga yang diproksikan oleh BI rate (RRF). * signifikan pada $5 \% ; * *$ signifikan pada $1 \%$ 
Variabel RET merupakan rata-rata return bulanan dari semua saham. Nilai maksimum dan minimum yang pernah dicapai masing-masing 0,400 dan -0,369. Selama periode penelitian rata-rata keseluruhan dari return sebesar 0,003. Standar deviasi dari RET keseluruhan sebesar 0,091. Nilai statistik Shapiro-Wilk signifikan pada 1\% sehingga RET tidak terdistribusi normal. Sementara itu, semua nilai ADF statistik signifikan pada 1\% sehingga RET stasioner. Variabel NETFOR merupakan rasio net foreign terhadap volume transaksi bulanan saham. Nilai maksimum dan minimum yang pernah dicapai masing-masing 0,349 dan -0,325. Selama periode penelitian rata-rata keseluruhan dari net foreign sebesar 0,016. Nilai statistik Shapiro-Wilk signifikan pada $1 \%$ sehingga NETFOR tidak terdistribusi normal. Sementara itu, semua nilai ADF statistik signifikan pada $1 \%$ sehingga NETFOR stasioner.

Variabel ISSI merupakan hasil return bulanan dari indeks saham syariah Indonesia yang mencerminkan portofolio pasar saham syariah. Nilai maksimum dan minimum yang pernah dicapai masing-masing 0,066 dan -0,088. Selama periode penelitian rata-rata keseluruhan dari return ISSI sebesar 0,004. Standar deviasi dari ISSI sebesar 0,034. Nilai statistik Shapiro-Wilk signifikan pada $1 \%$ sehingga IHSG tidak terdistribusi normal. Sementara itu, nilai ADF statistik signifikan pada $1 \%$ sehingga IHSG stasioner. Variabel TURN merupakan stock turnover yang merepresentasikan likuiditas saham. Nilai maksimum dan minimum yang pernah dicapai masingmasing 191,951 dan 2,485. Selama periode penelitian rata-rata keseluruhan dari TURN sebesar 28,756. Standar deviasi dari TURN keseluruhan sebesar 23,093. Nilai statistik Shapiro-Wilk signifikan pada $1 \%$ sehingga TURN tidak terdistribusi normal. Sementara itu, nilai ADF statistik signifikan pada $1 \%$ sehingga TURN stasioner.

Variabel IPI merupakan tingkat pertumbuhan produksi industri yang dapat mencerminkan pertumbuhan ekonomi. Nilai maksimum dan minimum yang pernah dicapai masing-masing 0,142 dan -0,134. Selama periode penelitian rata-rata keseluruhan dari IPI sebesar 0,004. Standar deviasi dari IPI keseluruhan sebesar 0,035. Nilai statistik Shapiro-Wilk signifikan pada $1 \%$ sehingga IPI tidak terdistribusi normal. Sementara itu, nilai ADF statistik signifikan pada 1\% sehingga IPI stasioner. VIX adalah log natural dari indeks volatilitas yang mengukur sentimen global. Nilai rata-rata VIX sebesar 2,709. Standar deviasi sebesar 0,229. Nilai maksimal dan minimal yang dicapai yakni 3,347 dan 2,252. Nilai Shapiro-Wilks dan ADF signifikan pada 1\% sehingga VIX tidak terdistribusi normal namun stasioner pada tingkat level. 
KURS adalah tingkat perubahan kurs rupiah terhadap US \$. Nilai rata-rata KURS sebesar 0,005. Standar deviasi sebesar 0,022. Nilai maksimal dan minimal yang dicapai yakni 0,061 dan 0,068. Nilai Shapiro-Wilks dan ADF signifikan pada 1\% sehingga KURS tidak terdistribusi normal namun stasioner pada tingkat level. INF adalah tingkat perubahan harga bulanan dalam $\%$. Nilai rata-rata INF sebesar 0,001. Standar deviasi sebesar 0,032. Nilai maksimal dan minimal yang dicapai yakni -0,280 dan 0,045. Nilai Shapiro-Wilks dan ADF signifikan pada 1\% sehingga INF tidak terdistribusi normal namun stasioner pada tingkat level. RRF adalah tingkat bunga pada aset yang bebas risiko. Nilai rata-rata RRF sebesar 0,005. Standar deviasi sebesar 0,001. Nilai maksimal dan minimal yang dicapai yakni 0,004 dan 0,006. Nilai Shapiro-Wilks dan ADF signifikan pada $1 \%$ sehingga RRF tidak terdistribusi normal namun stasioner pada tingkat level.

Tabel 5. Matriks Korelasi antar Variabel

\begin{tabular}{|c|c|c|c|c|c|c|c|c|c|c|}
\hline & RET & NETFOR & IHSG & TURN & MTB & IPI & VIX & KURS & INF & RRF \\
\hline RET & 1,000 & & & & & & & & & \\
\hline NETFOR & $0,198^{* *}$ & 1,000 & & & & & & & & \\
\hline IHSG & $0,473^{* *}$ & 0,054 & 1,000 & & & & & & & \\
\hline TURN & $0,083^{* *}$ & 0,020 & 0,008 & 1,000 & & & & & & \\
\hline MTB & 0,038 & $-0,045$ & $-0,006$ & $-0,286^{* *}$ & 1,000 & & & & & \\
\hline IPI & 0,030 & $-0,010$ & 0,047 & 0,033 & $-0,008$ & 1,000 & & & & \\
\hline VIX & $-0,055$ & $0,096^{* *}$ & $-0,207^{* *}$ & 0,027 & $-0,015$ & $0,076^{* *}$ & 1,000 & & & \\
\hline KURS & $-0,276$ & $-0,033$ & $-0,536^{* *}$ & 0,001 & 0,001 & 0,019 & $0,125^{* *}$ & 1,000 & & \\
\hline INF & $-0,055$ & 0,057 & $-0,056^{* *}$ & $-0,020$ & 0,005 & $-0,012$ & $-0,054$ & $0,036^{*}$ & 1,000 & \\
\hline RRF & 0,043 & $0,064^{* *}$ & $-0,027$ & $0,065^{\text {** }}$ & 0,001 & $-0,004$ & $0,245^{* *}$ & $0,079^{*}$ & $-0,107^{* *}$ & 1,000 \\
\hline
\end{tabular}

Tabel ini menampilkan matriks korelasi antar variabel. ** dan * signifikan pada $5 \%$ dan $1 \%$

Hasil Tabel 5 menunjukan matriks korelasi variabel-variabel yang digunakanan pada penelitian ini. Korelasi antar variabel yang di atas yang nilai koefisiennya kurang dari 0,80. Menurut Gujarati (2006), nilai koefisien di bawah 0,08 dapat disimpulkan tidak ada multikolinieritas antar variabel.

\section{Hasil Analisis}

Hipotesis 1 dan 2 menguji pengaruh antara return dan net foreign buy atau sebaliknya. Penelitian ini menggunakan two-stage least square (TSLS) untuk menguji hipotesis 1 dan 2. Metode digunakan untuk menguji pengaruh satu arah (directional) dengan memperhatikan potensi adanya hubungan simultan (bi-directional) antara return dan net foreign flow. Jika return berpengaruh terhadap net foreign flow atau sebaliknya maka diduga terdapat hubungan simultan. Untuk membuktikan hipotesis tersebut, penelitian ini menggunakan panel vector autoregressive (PVAR). 
Tabel 6. Hasil Analisis Two-Stage Least Square

\begin{tabular}{|c|c|c|c|c|}
\hline & \multicolumn{2}{|c|}{ RET $_{\text {it }}$} & \multicolumn{2}{|c|}{$\mathbf{N F}_{\text {it }}$} \\
\hline & FE & RE & FE & RE \\
\hline \multicolumn{5}{|c|}{ Panel A : Hasil estimasi koefisien dan p-value } \\
\hline \multirow[t]{2}{*}{$\mathrm{NF}_{\text {it }}$} & $0,162^{* *}$ & $0.163^{* *}$ & & \\
\hline & $(0,043)$ & $(0,044)$ & & \\
\hline \multirow{2}{*}{\multicolumn{3}{|c|}{$\mathrm{RET}_{\text {it }}$}} & $0,404^{* * *}$ & $0,388^{* * *}$ \\
\hline & & & $(0,002)$ & $(0,003)$ \\
\hline \multirow[t]{2}{*}{$\mathrm{TURN}_{\mathrm{it}}$} & $0,0006^{* * *}$ & $0,0002^{* * *}$ & & \\
\hline & $(0,000)$ & $(0,007)$ & & \\
\hline \multirow[t]{2}{*}{ ISSI $_{t}$} & $1,167^{* * *}$ & $1,171^{* * *}$ & & \\
\hline & $(0,000)$ & $(0,000)$ & & \\
\hline \multirow[t]{2}{*}{ KURS $_{\mathrm{t}}$} & $-0,127$ & $-0,124$ & & \\
\hline & $(0,302)$ & $(0,317)$ & & \\
\hline \multirow[t]{2}{*}{$\mathrm{NF}_{\mathrm{it}-1}$} & & & $-0,0072$ & 0,0001 \\
\hline & & & $(0,797)$ & $(0,997)$ \\
\hline \multirow[t]{2}{*}{ VIX $_{t}$} & & & $0,0914^{* * *}$ & $0,0904^{* * *}$ \\
\hline & & & $(0,001)$ & $(0,001)$ \\
\hline \multirow[t]{2}{*}{$\mathrm{INF}_{\mathrm{t}}$} & & & $0,502^{* * *}$ & $0,501^{* * *}$ \\
\hline & & & $(0,007)$ & $(0,007)$ \\
\hline \multirow[t]{2}{*}{$\mathrm{RRF}_{\mathrm{t}}$} & & & 8,674 & 8,697 \\
\hline & & & $(0,155)$ & $(0,154)$ \\
\hline \multirow[t]{2}{*}{$\mathrm{C}$} & $-0,0231^{* * *}$ & $-0,0116^{* * *}$ & $-0,277^{* * *}$ & $-0,275^{\text {**** }}$ \\
\hline & $(0,000)$ & $(0,003)$ & $(0,000)$ & $(0,000)$ \\
\hline Obs & 1245 & 1245 & 1245 & 1245 \\
\hline R-Square & 0,232 & 0,240 & 0,055 & 0,056 \\
\hline S-H Stat $\left(\chi^{2}\right)$ & 5,420 & 6,117 & 0,237 & 0,099 \\
\hline $\operatorname{Hausman}\left(\chi^{2}\right)$ & & & & \\
\hline
\end{tabular}

Tabel ini melaporkan hasil regresi panel Two-Stages Least Square (TSLS). Setiap model diestimasi menggunakan metode Fixed Effect (FE) dan Random Effect (RE) dengan robust standard error untuk mengatasi heteroskedastisitas. Panel A menunjukkan nilai koefisien dan t-statistik (dalam kurung). Panel B berisi informasi uji spesifikasi model meliputi Uji SarganHansen (S-H) dengan HO: overidentifikasi valid; dan uji Hausman untuk pemiliham model terbaik dengan H0: RE atau FE tidak berbeda; Ha: FE lebih baik dibanding RE. * signifikan pada 10\%, ** signifikan pada 5\%, dan *** signifikan pada 1\%.

\section{Hipotesis 1: Net Foreign Flow Berpengaruh Positif Terhadap Return Saham}

Hasil uji hipotesis 1 pada Tabel 6 menunjukkan bahwa variabel net foreign (NF) mempunyai nilai koefisien sebesar 0,162 di pengujian fixed effect (FE), artinya pada setiap kenaikan 1 satuan NF akan menyebabkan kenaikan pada nilai RET sebesar 0,162 satuan. Nilai pvalue NF pada hipotesis 1 yang bernilai sebesar 0,043 menunjukkan bahwa net foreign (NF) berpengaruh positif signifikan terhadap return (return). Sedangkan di pengujian menggunakan random effect mempunyai nilai koefisien sebesar 0.163 , artinya pada setiap kenaikan 1 satuan NF akan menyebabkan kenaikan pada nilai NF sebesar 0,163 satuan. Nilai p-value NF pada hipotesis 1 yang bernilai sebesar 0,044 menunjukkan bahwa net foreign (NF) berpengaruh positif signifikan terhadap return (return). 


\section{Hipotesis 2: Return Berpengaruh Positif Terhadap Net Foreign fLow}

Hasil uji hipotesis 2 pada Tabel 7 menunjukkan bahwa variabel return (RET) mempunyai nilai koefisien sebesar 0,404 di pengujian fixed effect (FE), artinya pada setiap kenaikan 1 satuan RET akan menyebabkan kenaikan pada nilai NF sebesar 0,404 satuan. Nilai p-value RET pada hipotesis 2 yang bernilai sebesar 0,002 menunjukkan bahwa return (RET) berpengaruh positif signifikan terhadap net foreign (NF). Sedangkan di pengujian menggunakan random effect mempunyai nilai koefisien sebesar 0,388, artinya pada setiap kenaikan 1 satuan RET akan menyebabkan kenaikan pada nilai NF sebesar 0,388 satuan. Nilai p-value RET pada hipotesis 2 yang bernilai sebesar 0,003 menunjukkan bahwa return (RET) berpengaruh positif signifikan terhadap net foreign (NF).

\section{Variabel Kontrol}

Variabel Turn di pasar merepresentasikan tingkat optimisme investor dalam bertransaksi. Variabel Stock turn (TURN) mempunyai nilai koefisien sebesar 0,0006 di pengujian fixed effect, artinya pada setiap kenaikan 1 satuan TURN akan menyebabkan kenaikan pada nilai RET sebesar 0,162 satuan. Nilai p-value TURN 0,000 yang bernilai sebesar 0,000 menunjukkan bahwa TURN signifikan berpengaruh terhadap return (RET). Sedangkan di pengujian menggunakan random effect mempunyai nilai koefisien sebesar 0,0002, artinya pada setiap kenaikan 1 satuan TURN akan menyebabkan kenaikan pada nilai RET sebesar 0,002 satuan. Nilai p-value TURN yang bernilai sebesar 0,007 menunjukkan bahwa return TURN berpengaruh positif signifikan terhadap return (RET).

Variabel ISSI mempunyai nilai koefisien sebesar 1,167 di pengujian fixed effect, artinya pada setiap kenaikan 1 satuan ISSI akan menyebabkan kenaikan pada nilai RET sebesar 1,171 satuan. Nilai p-value ISSI yang bernilai sebesar 0,000 menunjukkan bahwa ISSI signifikan berpengaruh terhadap return (RET). Sedangkan di pengujian menggunakan random effect mempunyai nilai koefisien sebesar 1,171, artinya pada setiap kenaikan 1 satuan ISSI akan menyebabkan kenaikan pada nilai RET sebesar 1,171 satuan. Nilai p-value ISSI yang bernilai sebesar 0,000 menunjukkan bahwa return TURN berpengaruh positif signifikan terhadap return (RET).

Variabel Kurs akan merefleksikan sensitifitas dari investor asing terhadap pergerakan nilai tukar. Variabel KURS mempunyai nilai koefisien sebesar $-0,127$ di pengujian fixed effect, artinya pada setiap kenaikan 1 satuan KURS akan menyebabkan kenaikan pada nilai RET sebesar 
$-0,127$ satuan. Nilai p-value KURS yang bernilai sebesar 0,300 menunjukkan bahwa KRS tidak signifikan berpengaruh terhadap return (RET). Sedangkan di pengujian menggunakan random effect mempunyai nilai koefisien sebesar -0,124, artinya pada setiap kenaikan 1 satuan KURS akan menyebabkan kenaikan pada nilai RET sebesar -0,124 satuan. Nilai p-value ISSI yang bernilai sebesar 0,317 menunjukkan bahwa return KURS tidak berpengaruh signifikan terhadap return $(\mathrm{RET})$.

Variabel $\mathrm{NF}_{\text {it- } 1}$ mempunyai nilai koefisien sebesar $-0,0072$ di pengujian fixed effect, artinya pada setiap kenaikan 1 satuan $\mathrm{NF}_{\text {it-1 }}$ akan menyebabkan kenaikan pada nilai NF sebesar $-0,0072$ satuan. Nilai p-value $\mathrm{NF}_{\mathrm{it}-1}$ yang bernilai sebesar 0,797 menunjukkan bahwa $\mathrm{NF}_{\mathrm{it}-1}$ tidak signifikan berpengaruh terhadap net foreign (NF). Sedangkan di pengujian menggunakan random effect mempunyai nilai koefisien sebesar 0,0001, artinya pada setiap kenaikan 1 satuan $\mathrm{NF}_{\mathrm{it}-1}$ akan menyebabkan kenaikan pada nilai NF sebesar 0,0001 satuan. Nilai p-value $\mathrm{NF}_{\mathrm{it}-1}$ yang bernilai sebesar 0,997 menunjukkan bahwa $\mathrm{NF}_{\mathrm{it}-1}$ tidak berpengaruh signifikan terhadap net foreign (NF).

Variabel VIX $_{\mathrm{t}}$ mempunyai nilai koefisien sebesar 0,0914 di pengujian fixed effect, artinya pada setiap kenaikan 1 satuan VIX $_{\mathrm{t}}$ akan menyebabkan kenaikan pada nilai NF sebesar 0,0914 satuan. Nilai p-value VIX $_{t}$ yang bernilai sebesar 0,001 menunjukkan bahwa VIX signifikan berpengaruh positif terhadap net foreign (NF). Sedangkan di pengujian menggunakan random effect mempunyai nilai koefisien sebesar 0,0904 artinya pada setiap kenaikan 1 satuan VIX $\mathrm{t}_{\mathrm{t}}$ akan menyebabkan kenaikan pada nilai NF sebesar 0,0904 satuan. Nilai p-value VIX $_{\mathrm{t}}$ yang bernilai sebesar 0,001 menunjukkan bahwa VIX $_{\mathrm{t}}$ tidak berpengaruh signifikan terhadap net foreign (NF).

Variabel $\mathrm{INF}_{\mathrm{t}}$ mempunyai nilai koefisien sebesar 0,502 di pengujian fixed effect, artinya pada setiap kenaikan 1 satuan $\mathrm{INF}_{\mathrm{t}}$ akan menyebabkan kenaikan pada nilai NF sebesar 0,502 satuan. Nilai p-value $\mathrm{INF}_{\mathrm{t}}$ yang bernilai sebesar 0,007 menunjukkan bahwa $\mathrm{INF}_{\mathrm{t}}$ signifikan berpengaruh positif terhadap net foreign (NF). Sedangkan di pengujian menggunakan random effect mempunyai nilai koefisien sebesar 0,501 artinya pada setiap kenaikan 1 satuan $\mathrm{INF}_{\mathrm{t}}$ akan menyebabkan kenaikan pada nilai NF sebesar 0,501 satuan. Nilai p-value $\mathrm{INF}_{\mathrm{t}}$ yang bernilai sebesar 0,001 menunjukkan bahwa $\mathrm{INF}_{\mathrm{t}}$ berpengaruh signifikan terhadap net foreign (NF).

Variabel $\mathrm{RRF}_{\mathrm{t}}$ mempunyai nilai koefisien sebesar 8,674di pengujian fixed effect, artinya pada setiap kenaikan 1 satuan $\mathrm{RRF}_{\mathrm{t}}$ akan menyebabkan kenaikan pada nilai NF sebesar 8,674 satuan. Nilai $\mathrm{p}$-value $\mathrm{RRF}_{\mathrm{t}}$ yang bernilai sebesar 0,155 menunjukkan bahwa $\mathrm{INF}_{\mathrm{t}}$ tidak signifikan berpengaruh positif terhadap net foreign (NF). Sedangkan di pengujian menggunakan random 
effect mempunyai nilai koefisien sebesar 8,697 artinya pada setiap kenaikan 1 satuan $\mathrm{RRF}_{\mathrm{t}}$ akan menyebabkan kenaikan pada nilai NF sebesar 8,697 satuan. Nilai p-value $R_{R} F_{t}$ yang bernilai sebesar 0,154 menunjukkan bahwa $\mathrm{RRF}_{\mathrm{t}}$ tidak berpengaruh signifikan terhadap net foreign (NF).

Hasil estimasi TSLS pada Panel B (Tabel 4.3) baik untuk metode FE (fixed effect) dan $\mathrm{RE}$ (random effect) menunjukkan nilai $\chi^{2}$ tidak signifikan sehingga disimpulkan bahwa overidentifikasi pada instrumental variabel valid. Uji Hausman menunjukkan tidak menolak H0 pada persamaan RET sehingga FE atau RE dapat digunakan. Sementara itu pada persamaan NF, uji Hausman menolak H0 sehingga FE lebih baik dibanding RE. Secara umum baik dengan FE atau RE, RET berpengaruh positif terhadap NF begitu juga NF berpengaruh positif terhadap RET. Dengan demikian terdapat hubungan simultan (bi-directional) antara aliran modal asing dan kinerja saham. Kesimpulan tersebut diuji lebih lanjut dengan panel VAR (PVAR).

PVAR mensyaratkan asumsi stasioneritas pada semua variabel endogen. Berdasarkan hasil uji stasioneritas pada Tabel 4.1, semua variabel stasioner pada tingkat level sehingga dapat dilakukan analisis PVAR. Pemilihan model terbaik didasarkan pada penentuan lag optimal dan uji stabilitas model. Berdasarkan Tabel 7, model PVAR optimal pada lag 1. Hasil ini terlihat pada nilai MBIC, MAIC, dan MQIC yang paling kecil. Selain itu hasil uji stabilitas PVAR pada Grafik 2, nilai modulus terletak pada unit circle.

Tabel 7 Pemilihan Lag Optimal

\begin{tabular}{rrrrrrrrr}
\hline Lag & \multicolumn{1}{l}{ CA } & J-Stat & P-value & \multicolumn{1}{l}{ MBIC } & \multicolumn{1}{c}{ MAIC } & \multicolumn{1}{c}{ MQIC } & Obs & Panel \\
\hline 1 & 0,010 & 17,928 & 0,328 & -91.155 & $-95,10$ & $-44,63$ & 1170 & 17 \\
2 & 0,016 & 12,337 & 0,419 & -65.295 & $-72,43$ & $-34,58$ & & \\
3 & 0,022 & 4,888 & 0,769 & -46.256 & $-51,62$ & $-26,39$ & & \\
4 & 0,037 & 2,097 & 0,717 & -20.226 & $-26,16$ & $-13,54$ & & \\
\hline
\end{tabular}

Tabel ini menyajikan kriteria pemilihan model yang terdiri dari coefficient of assurance (CA), Hansen JStatistic (J-Stat), Bayesian Information Criterion (MBIC), Akaike Information Criterion (MAIC), dan Hannan-Quinon Information Criterion (MQIC). 


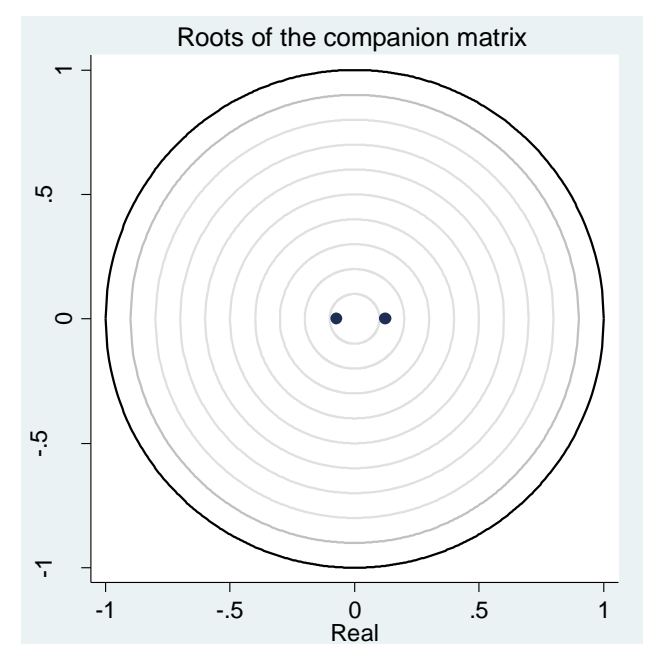

Grafik 2. Uji Stabilitas Panel VAR

Tabel 8 menunjukkan hasil estimasi PVAR dan uji spesifikasi model. Panel B menampilkan Uji Hansen J-Statistik yang menyimpulkan bahwa nilai $\chi^{2}$ tidak signifikan sehingga tidak menolak $\mathrm{H}_{0}$. Dengan kata lain model PVAR sudah terspesifikasi dengan baik. Sementara itu panel A menampilkan hasil estimasi parameter yang terdiri dari nilai koefisien dan z-statistik. Variabel endogen terdiri dari return dan net foreign sehingga terdapat 2 persamaan. Hasil menunjukkan return dipengaruhi oleh return dan net foreign satu periode sebelumnya pada nilai kritis 5\%. Di sisi lain tidak ada variabel yang mempengarui net foreign.

Tabel 8. Hasil Estimasi Panel Vector Autoregressive (PVAR)

\begin{tabular}{lcc}
\hline & RET & NETFOR \\
\hline Panel A: Hasil estimasi parameter & $-0,029$ & $-0,137^{* *}$ \\
RET $_{\mathrm{t}-1}$ & $(0,300)$ & $(0,040)$ \\
& $-0,028^{* * *}$ & 0,008 \\
NETFOR $_{\mathrm{t}-1}$ & $(0,009)$ & $(0,771)$ \\
& $0,0014^{* * *}$ & $0,001^{*}$ \\
TURN & $(0,000)$ & $(0,078)$ \\
& $1,268^{* * *}$ & $0,397^{* *}$ \\
ISSI & $(0,000)$ & $(0,021)$ \\
& $-0,020$ & $-0,088$ \\
IPI & $(0,762)$ & $(0,585)$ \\
& & \\
Panel B: Uji spesifikasi model & 1230 & 1230 \\
Observations & & \\
Hansen J- ${ }^{2}$ (16) & & 27,59 \\
\hline Tabel ini menampilkan hasil analisis panel vector autoregressive (PVAR) dengan metode Generalized Method of Moment \\
(GMM). Tingkat return (RET) dan net foreign buy (NETFOR) merupakan variabel endogen sementara stock turnover (TURN), \\
return indeks syariah (ISSI) dan pertumbuhan produksi industri (IPI) sebagai variabel eksogen. Variabel instrumen terdiri dari \\
L.(1 /5).(RET NETFOR), ISSI, TURN, dan IPI. Panel A menunjukkan koefisien dan nilai $z$-statistic sedangkan panel B adalah \\
uji spesifikasi model yakni Hansen J-Statistic dengan H0: overidentifikasi bersifat valid. Level signifikansi ${ }^{* * *} 1 \%,{ }^{* *} 5 \%$, dan ${ }^{*}$ \\
10\%
\end{tabular}


Hasil uji hipotesis 1 dan 2 pada tabel 4.5 menunjukkan bahwa variabel RET $\mathrm{t}-1$ mempunyai nilai koefisien sebesar -0,137, artinya pada setiap kenaikan 1 satuan RET $_{t-1}$ akan menyebabkan kenaikan pada nilai NETFOR sebesar $-0,137$ satuan. Nilai p-value RET $_{t-1}$ yang bernilai sebesar 0,040 menunjukkan bahwa $\mathrm{RET}_{\mathrm{t}-1}$ berpengaruh negatif signifikan terhadap NETFOR.Sedangkan variabel NETFOR $\mathrm{t}_{-1}$ mempunyai nilai koefisien sebesar $-0,028$, artinya pada setiap kenaikan 1 satuan NETFOR akan menyebabkan kenaikan pada nilai RET sebesar 0,388 satuan. Nilai p-value NETFOR $_{t-1}$ yang bernilai sebesar 0,009 menunjukkan bahwa NETFOR $_{t-1}$ berpengaruh signifikan negatif terhadap return (RET).

Variabel TURN mempunyai nilai koefisien sebesar 0,0014, artinya pada setiap kenaikan 1 satuan TURN akan menyebabkan kenaikan pada nilai RET sebesar 0,0014 satuan. Nilai p-value TURN yang bernilai sebesar 0,000 menunjukkan bahwa TURN berpengaruh positif signifikan terhadap RET. Sedangkan Variabel TURN untuk NETFOR mempunyai nilai koefisien sebesar 0,001, artinya pada setiap kenaikan 1 satuan TURN akan menyebabkan kenaikan pada nilai NETFOR sebesar 0,001 satuan. Nilai p-value TURN yang bernilai sebesar 0,078 menunjukkan bahwa TURN tidak berpengaruh terhadap NETFOR.

Variabel ISSI mempunyai nilai koefisien sebesar 1,268, artinya pada setiap kenaikan 1 satuan ISSI akan menyebabkan kenaikan pada nilai RET sebesar 1,268 satuan. Nilai p-value ISSI yang bernilai sebesar 0,000 menunjukkan bahwa ISSI berpengaruh positif signifikan terhadap RET. Sedangkan Variabel ISSI untuk NETFOR mempunyai nilai koefisien sebesar 0,397, artinya pada setiap kenaikan 1 satuan ISSI akan menyebabkan kenaikan pada nilai NETFOR sebesar 0,397 satuan. Nilai p-value ISSI yang bernilai sebesar 0,021 menunjukkan bahwa ISSI berpengaruh signifikan positif terhadap NETFOR.

Variabel IPI mempunyai nilai koefisien sebesar -0,020, artinya pada setiap kenaikan 1 satuan IPI akan menyebabkan kenaikan pada nilai RET sebesar -0,020 satuan. Nilai p-value IPI yang bernilai sebesar 0,762 menunjukkan bahwa IPI tidak berpengaruh terhadap RET. Sedangkan Variabel IPI untuk NETFOR mempunyai nilai koefisien sebesar -0,088, artinya pada setiap kenaikan 1 satuan IPI akan menyebabkan kenaikan pada nilai NETFOR sebesar -0,088 satuan. Nilai p-value IPI yang bernilai sebesar 0,585 menunjukkan bahwa IPI tidak berpengaruh terhadap NETFOR.

Tabel 9 menampilkan hasil yang didapatkan dari uji kausalitas Granger Wald Test. Hubungan kausalitas terbukti jika p-value signifikan pada dua hipotesis. Hasil uji kausalitas 
menunjukkan nilai p-value pada net foreign sebesar 0,007 dan p-value pada return sebesar 0,028. Kedua hipotesis nol signifikan sehingga net foreign flow dan return memiliki hubungan kausalitas.

Tabel 9. Hasil Uji Kausalitas Granger

\begin{tabular}{lccc}
\hline Hipotesis nol & Obs & Chi $^{2}$ & p-value \\
\hline Net foreign does not Granger Cause Return & 660 & 7,375 & 0,007 \\
Return does not Granger Cause Net foreign & 660 & 4,801 & 0,028 \\
\hline
\end{tabular}

\section{Pembahasan Hasil}

\section{Hipotesis 1}

Hasil hipotesis 1, yaitu net foreign flow berpengaruh positif terhadap return saham syariah di Jakarta Islamic Index diterima melalui pengujian PVAR. Masuknya aliran modal asing dianggap memiliki dampak yang positif terhadap return saham. Namun sebaliknya, keluarnya modal asing dalam jumlah yang besar juga dapat memberi dampak yang negatif pada perubahan harga saham dan juga return saham. Hasil temuan penelitian ini memperkuat penelitian sebelumnya yang dilakukan oleh Vo (2017) yang menunjukkan bahwa transaksi investor asing memiliki dampak yang signifikan terhadap harga saham di pasar saham negara berkembang. Lebih penting lagi, jika investor asing bereaksi terhadap informasi secara bersamaan, mereka dapat mengguncang harga saham. Jeon dan Moffett (2010) juga memberikan bukti bahwa terdapat dampak signifikan dari perdagangan investor asing pada return saham di pasar saham Korea. Hal ini seirama dengan penemuan Wang (2007), yang melakukan penelitian di pasar modal Indonesia dan Thailand, menunjukkan bahwa meskipun net foreign sell hanya menyumbang sebagian kecil dari perdagangan harian, namun ini memiliki kekuatan penjelas tertinggi untuk Volatilitas pasar di kedua negara tersebut.

Sapian \& Auzairy (2015) dan Adaoglu \& Katircioglu (2013) yang menyatakan bahwa peningkatan net foreign flows yang diinvestasi di pasar saham Indonesia disebabkan dengan meningkatnya return yang diterima oleh investor asing dimasa lalu. Sehingga investor tersebut akan meningkatkan modal investasinya pada saham tersebut seiring dengan meningkatnya return yang diterima.

Selain itu, meningkatnya partisipasi investor asing terhadap permintaan saham dapat menyebabkan peningkatan likuiditas suatu pasar saham (Syamala et al., 2014). Kinerja positif pasar saham dimasa lalu akan menjadi faktor penting terkait perilaku investor asing dalam 
melakukan investasi. Hasil penelitian Chandra (2012) menjelaskan aliran modal asing berpengaruh positif terhadap return saham yang diperoleh oleh investor asing. Investor asing di pasar saham menggunakan strategi momentum dalam melakukan transaksi saham. Perilaku investor asing dalam bertransaksi di pasar saham lebih banyak melakukan aksi beli saham daripada menjual saham (Samarakoon, 2009).

\section{Hipotesis 2}

Hasil penelitian hipotesis 2 pengaruh return signifikan positif terhadap aliran modal asing (net foreign flow) yang di analisis menggunakan PVAR. Hasil temuan penelitian ini selaras dengan penelitian yang di lakukakan oleh (Froot, 2001; French dan Naka, 2008 dan Gou, 2015). Realisasi return saham yang diperoleh oleh investor asing dimasa lalu dapat memengaruhi aliran modal asing yang semakin tinggi diinvestasikan di pasar saham (French dan Vishwakarma, 2013).

Penelitian yang dilakukan oleh Sungkono (2013) menunjukkan adanya perdagangan investor asing berpengaruh positif terhadap harga saham, dimana pengaruh dari perdagangan investor asing terhadap harga saham lebih besar pada saham-saham yang termasuk dalam indeks LQ45. Kemudian, pengaruh dari adanya perdagangan investor asing terhadap harga saham dinilai memberikan nilai kapasitas yang pasar yang lebih besar. Penelitian yang dilakukan oleh Sungkono (2013) menunjukkan adanya perdagangan investor asing berpengaruh positif terhadap harga saham, dimana pengaruh dari perdagangan investor asing terhadap harga saham lebih besar pada saham-saham yang termasuk dalam indeks LQ45. Kemudian, pengaruh dari adanya perdagangan investor asing terhadap harga saham dinilai memberikan nilai kapasitas yang pasar yang lebih besar. Hasil penelitian Wang and Haizhi Wang (2014) dengan menggunakan metode VAR mendapatkan hasil bahwa return pasar modal berkaitan secara signifikan dengan investasi asing masa lalu namun tidak dan sebaliknya namun tidak dapat membuktikan adanya teori positive feedback trader.

Investor asing cenderung lebih sentitif terhadap informasi di pasar saham, return saham merupakan salah satu sinyal informasi yang digunakan oleh investor asing dalam menilai kondisi pasar saham suatu negara (Brennal etal., 2005). Peningkatan aliran modal asing di pasar saham disebabkan oleh sinyal informasi dari return yang dihasilkan saat ini dan dimasa lalu. Return saham secara positif akan berdampak terhadap aliran modal asing yang diinvestasikan di pasar saham suatu negara (Brennan dan Cao, 1997). Investor asing melakukan penilaian terhadap 
return yang terima sebagai acuan keputusan alokasi investasi di pasar saham suatu negara (Brennan et al., 2005). Retun saham dapat digunakan untuk memprediksi aliran modal asing yang masuk di pasar saham, return saham yang positif disuatu negara akan direspon oleh investor asing dengan mendorong peningkatan aliran modal asing yang diinvestasikan ke pasar saham (Potter, 1995).

Dengan demikian, dalam penelitian ini terdapat hubungan kausalitas antara aliran modal asing dan return saham di indek JII selaras dengan penelitian sebelumnya (Ülkü dan İkizlerli; Froot, 2001; French dan Naka, 2008 dan Gou, 2015). Hubungan sebab akibat keduanya dapat di anggap sebagai informasi penting yang mengisyartakan tentang faktor fundamental ekonomi dan prospek pasar saham suatu negara oleh investor asing. Investor asing yang optimis akan cenderung memproses informasi yang berharga dari return yang diperoleh saat ini, dan berinvestasi lebih banyak ketika pasar saham memberikan sinyal informasi tentang prospek keuntungan yang akan diperoleh (Guo, 2015). Hubungan kausalitas yang positif dapat diartikan bahwa investor asing menggunakan strategi momentum atau feedback tranding positif. Perilaku investor asing di pasar saham menyiratkan return chaser, yang berarti bahwa return yang tinggi sangat terkait dari peningkatan aliran modal asing yang diinvestasikan dan juga sebaliknya (Sapian dan Auzairy, 2015). Positif feedback tranding disebabkan oleh aliran modal asing bersih positif dan signifikan memengaruhi return di pasar saham suatu negara, dan return saham memengaruhi aliran modal asing yang masuk ke pasar saham (Froot, 2001). Kenaikan tren di pasar saham membuat investor membeli saham yang winner dan menjual saham loser. Dengan demikian, investor asing menganggap bahwa saham syariah JII merupakan saham pilihan karena memiliki beberapa karakteristik yang dapat dianggap menguntungkan dan tentunya telah melewati beberapa proses dan syarat pemilihan yang ketat. Misalnya tingkat likuiditas yang tinggi dan debt to equity yang tidak boleh lebih dari $45 \%$. Selain itu pasar saham syariah mampu memberikan informasi bagi investor asing untuk membantu investor dalam mengelola strategi perdagangan yang sukses dan untuk memaksimalkan manfaat diversifikasi (Hkiri, et al., 2017).

\section{KESIMPULAN DAN SARAN}

Kesimpulan yang dapat diambil dari penelitian "net foreign flow dan interaksinya dengan return saham di indeks JII" menunjukkan aliran modal asing berpengaruh signifikan positif terhadap return saham. Hal ini disebabkan oleh optimisme investor asing terhadap perekonomian 
dan prospek pasar saham. Hasil penelitian hipotesis 2 return saham berpengaruh signifikan postif terhadap aliran modal asing. Realisasi return yang sesuai diharapkan diterima oleh investor asing akan membuat peningkatan aliran modal asing yang masuk ke indeks pasar saham JII. Selanjutnya, Hasil pengujian granger PVAR terdapat hubungan kausalitas signifikan positif antara aliran modal asing dan return saham. Investor asing dalam berinvestasi menggunakan strategi momentum ataupun feedback trading positif. Investor asing menganggap bahwa saham syariah JII merupakan saham pilihan karena memiliki beberapa karakteristik yang dapat dianggap menguntungkan dan tentunya telah melewati beberapa proses dan syarat pemilihan yang ketat, sehingga dapat membantu investor dalam mengelola strategi perdagangan dan mengatur portofolio investasi yang baik dan dapat memaksimalkan manfaat diversifikasi.

Penelitian ini diharapkan dapat menjadi sumber referensi bagi pihak manajerial perusahaan. Pihak manajerial perusahaan memiliki pengaruh terhadap return saham di perusahan. Hal ini berkaitan dengan laporan kinerja keuangan, utang perusahaan, laba perusahaan, maupun asset perusahaan. Investor asing akan menilik perusahaan ketika mendapatkan informasi laporan kinerja keuangan yang baik. Namun, perlu diperhatikan oleh pihak internal perusahaan atau pihak manajerial perusahan untuk memperhatikan karakteristik dari investor asing yang akan memanamkan modalnya. Penelitian ini memiliki beberapa keterbatasan yang diharapkan dapat disempurnakan pada penelitian selanjutnya. Seperti yang sudah dijelaskan, ketika tindakan Setidaknya ada lima keterbatasan utama yang dimiliki pada penelitian ini yaitu 1) Periode pengamatan penelitian ini tidak mencakup kondisi saat terjadi krisis, sehingga generalisasi terbatas pada kondisi setelah krisis, 2)Penelitian ini hanya fokus pada indeks JII yang hanya terdiri dari 30 saham yang berkapitalisasi besar, penelitian selanjutnya dapat menambahkan sampel penelitian indeks ISSI yang sampel perusahaan lebih besar, 3)Penelitian selanjutnya dapat membandingkan saham syariah dan saham konvensional di Indonesia, 4) Penelitian selanjutnya dapat memisahkan antara investor asing instititual dan individual yang melakukan investasi di pasar saham Indonesia dan 5) Penelitian yang akan datang dapat menambahkan variabel keperilakuan atau aspek psikologi yang mendasari investor asing melakukan transaksi di pasar saham Indonesia. 


\section{REFERENSI}

Abbesa, B dan Trichillib, Y. 2015. Islamic Stock Markets and Potential Diversification Benefits. Borsa Istanbul Review. Vol. 15. Pp 93-105.

Adaoglu, C., dan Katircioglu, S, T. 2013. Foreign Investor Flows and "Blue Chip" Stock Returns. International Journal of Emerging Markets, Vol 8, 170-181.

Agarwal, S., Fairclothc, S., Liuc, L. dan Rhee G. 2008. Why Do Foreign Investors Underperform Domestic Investors in Trading Activities? Evidence From Indonesia. Journal of Financial Markets. Vol. 12. pp. 32-53.

Alam, N., Arshad, S., dan Rizvi, S.A. 2016. Do Islamic Stock Indices Perform better than Conventional Counterparts? An Empirical Investigation of Sectoral Efficiency. Review of Financial Economics. Vol. 31. pp. 108-114.

Al-Awadhi, Abdullah M. dan Dempsey, Michael. 2017. Social Norms and Market Outcomes: The effects of Religious Beliefs on Stock Markets. Journal of International Financial Markets, Institutions and Money. Vol. 50. pp. 119-134.

Bae, K. H., Ozoguz, A., Tan, H. dan Wirjanto, T.S. 2012. Do Foreigners Facilitate Information Transmission in Emerging Markets? Journal of Financial Economic. Vol. 105. pp. 209227.

Bae, S.C., Min, J.H. dan Jung, S. 2011. Trading Behavior, Performance, and Stock Preference of Foreigners, Local Institutions, and Individual Investors: Evidence from the Korean Stock Market. Asia Pacific Journal of Financial Studies. Vol. 40. pp. 199-239.

Baia, Shuming dan Koong, K.S. 2018. Oil Prices, Stock Returns, and Exchange Rates: Empirical Evidence from China and the United States. North American Journal of Economics and Finance. Vol. 44

Bekaert, G. dan Wu, G. 2000. Asymmetric Volatility and Risk in Equity Markets. Review of Financial Studies. Vol.13. pp. 1-42.

Boediono. 2000. Ekonomi Moneter. Edisi 3. Yogyakarta: BPFE.

Botosan, C.A., dan Plumlee, M.A. 2002. A Re-Examination of Disclosure Level and The Expected Cost of Equity Capital. Journal of Accounting Research. Vol. 40. Pp. 21-40.

Boyer, Brian dan Zheng, Lu. 2009. Investor Flows and Stock Market Returns. Journal of Empirical Finance. Vol.16, pp. 87-100.

Brennan, M, J., Henry, H., Strong, N., dan \& Xu, X. 2005. The Dynamics of International Equity Market Expectations. Journal of Financial Economics, Vol 77, 257-288.

Brennan, M, J., dan Cao, H, C. 1997. International Portfolio Investment Flows. The Journal of Financial, Vol 52, 1851-1880.

Brigham, Eugene F. dan Houston, Joel F. 2011. Dasar-dasar Manajemen. Keuangan Terjemahan. Edisi 10. Jakarta: Salemba Empat.

Chandra, A. 2012. Cause and Effect Between Fii Trading Behaviour and Stock Market Returns: The Indian experience. Journal of Indian Business Research, Vol 4, 286-300.

Chen, L., Johnson, S., Lin, J., dan Liu, Y. 2009. Information, Sophistication, and Foreign Versus Domestic Investors performance. Journal of Banking and Finance. Vol. 33. Pp. 16361651.

Choe, H., Kho, B.C. dan Stulz, R.M. 1999. Do Foreign Investors Destabilize Stock Markets? The Korean experience in 1997. Journal of Financial Economics. Vol. 54. pp. 227-264.

Clark, J dan Berko, E. 1997. Foreign Investment Fluctuations and Emerging Market Stock Return: The Case of Mexico. Federal Reserve Bank of New York Staff Report, No. 24. 
Darsono, Ali Sakti, Siti Aisyah, Adroecia Darwis, dan Enny Tin Suryanti. 2017. Dinamika Produk dan Akad Keuangan Syariah di Indonesia. Depok: Rajawali Pers

Dornbusch, R., Fischer, S. dan Startz, R. 2008. Makroekonomi. Jakarta: PT Media Global Edukasi.

Dvořák, T. 2005. Do Domestic Investors Have an Information Advantage? Evidence from Indonesia. The Journal of Finance. Vol. 60. pp. 817-839.

Dvorak, Tomas. 2001. Does Foreign Trading Destabilize Local Stock Markets? Department of Economics Williams College.

Elsiefy, Elsayed dan Moustafa, Elaa. 2017. Analyzing Foreign Investors Behavior in the Emerging Stock Market: Evidence from Qatar Stock Market. Accounting and Finance Research.

Fama, Eugene F dan French K.R. 1998. Taxes, Financing Decision and Firm Value. The Journal of Finance. Vol. LIII. pp. 819-843.

French, J, J., dan Vishwakarma, J, K. 2013. Volatility and foreign equity flows: evidence from the Philippines". Studies in Economics and Finance, Vol 30 ,4-21.

French, J. J., dan Li, W. 2017. Sentiment, Foreign Equity Flows, and Returns: Evidence From Thailand's Stock Markets. Research in International Business and Finance, Vol 42, 816831.

French, J. J., dan Naka, A. 2008. Dynamic Linkages Between U.S. Portfolio Equity Flows and Equity Returns in China and India. Economics of Emerging Markets. 67-97.

French, J.J. (2011), The Dynamic Interaction Between Foreign Equity Flows and Returns: Evidence from The Johannesburg Stock Exchange, The International Journal of Business and Finance Research, Vol. 5 No. 4, pp. 45-56.

Frensidy, B. 2008. Analisis Pengaruh Aksi Beli-Jual Asing, Kurs, dan Indeks Hang Seng terhadap Indeks Harga Saham Gabungan di Bursa Efek Indonesia dengan Model GARCH. Media Riset Bisnis dan Manajemen. 25-42.

Froot, K.A. dan Ramadorai, T. 2001. The Information Content of International Portfolio Flows. National Bureau of Economic Research.

Froot, KA, O'Connell, PGJ, dan Seasholes, MS. 2001. The Portfolio Flows of International Investors. Journal of Financial Economics, Vol. 59. pp. 151-139.

Griffin, J.M., Nardari, F. dan Stulz, R.M. 2004. Are Daily Cross-Border Equity Flows Pushed or Pulled? The Review of Economics and Statistics. Vol.86. pp. 641-657

Guo, L. 2015. Are U.S Investors Blindly Chasing Returns in Foreign Countries?. International Review of Economics \& Finance Volume, Vol 41, 309-334.

Halim, Abdul dan Mamduh M. Hanafi. 2009. Analisis Laporan Keuangan. Edisi 4. Yogyakarta: UPP STIM YKPN

Halim, Abdul. 2005. Analisis Investasi. Edisi Dua. Jakarta: Salemba Empat.

Hartono, Jogiyanto. 2010. Teori Portofolio dan Analisis Investasi. Edisi Keenam. Yogyakarta: BPFE.

Hkiri, B., Hammoudeh, S., Aloui, C., dan Yarovaya, S. 2017. Are Islamic Indexes a Safe Haven for Investors? An Analysis of Total, Directional and Net Volatility Spillovers Between Conventional and Islamic Indexes and Importance of Crisis Periods. Pacific-Basin Finance Journal. Vol. 43. pp. 124-150.

Husnan, Suad. 2010. Dasar-Dasar Teori Portofolio dan Analisis Sekuritas. Yogyakarta: UPP YKPN 
Jeon, J.Q. dan Moffet, C.M. 2010. Herding by Foreign Investors and Emerging Market Equity Returns: Evidence from Korea. International Review of Economics and Finance. Vol.19. pp. 698-710.

Kim, E.H., dan Singal, V. 2000. Are Open Markets Good For Foreign Investors and Emerging Nations? Journal of Applied Corporate Finance. Vol. 10. pp. 18-33

Kim, J., Landi, J. dan Yoo, S.S. 2009. Inter-temporal Examination of The Trading Activities of Foreign Investors in The Korean Stock Market. Pacific-Basin Finance Journal. Vol. 17. pp. 243-256.

Kim, W. dan Wei, S.J. 2002. Foreign Portfolio Investors Before and During a Crisis. Journal of International Economics. Vol. 56. pp. 77-96.

Lima, Shu Yi dan Siok Kun Sek. 2014. Exploring the Inter-Relationship between the Volatilities of Exchange Rate and Stock Return. Procedia Economics and Finance Vol.14, pp. 367376

Minton, B.A., dan Schrand, C. 1999. The Impact of Cash Flow Volatility on Discretionary Investment and The Costs of Debt and Equity Financing. Journal of Financial Economics. Vol.54, pp. 423-460.

Narayan, Paresh Kumar dan Bannigidadmath, Deepa. 2017. Does Financial News Predict Stock Returns? New Evidence from Islamic and Non-Islamic Stocks. Pacific-Basin Finance Journal, Vol. 42. pp. 24-45.

Nurmalasarie, E. 2015. Pengaruh Net Foreign Buy/Sell Pada Return Saham Perusahaan yang Terdaftar dalam Indeks LQ-45 Bursa Efek Indonesia. Yogyakarta: Perpusatakan UGM

O’Sullivan A, Steven M. S. dan Stephen, J. P. 2010. Macroeconomics 6th Edition: Principles: Applications, and Tools. New Jersey, USA: Pearson Education Inc.

Pal, Karam dan Ruhee, M. 2011. Impact of Macroeconomic Indicators on Indian Capital Market. The Journal of Risk Finance. Vol. 12 pp. 84-97

Pohan, Aulia. 2008. Potret Kebijakan Moneter Indonesia. Jakarta: Raja Persada.

Pompian, M, M. 2006. Behavioral Finance and Wealth Management: How to Build Optimal Portofolio that Account for Investor Biases. United States of America: Wiley Finance.

Porras, E., dan Ülkü, N. 2015. Foreigners' trading and stock returns in Spain. Journal of International Financial Markets, Institutions and Money Vol. Pp. 111-126

Potter, S, M. 1995. A Nonlinear Approach to US GNP”. Journal of Applied Econometrics, Vol $10,109-125$.

Rhee, S. G. dan Wang, J., 2009, Foreign Institutional Ownership and Stock Market Liquidity: Evidence from Indonesia. Journal of Banking and Finance. Vol. 33. Pp. 1312-1324.

Richards, A. 2005, Big Fish in Small Ponds: The Trading Behavior and Price Impact of Foreign Investors in Asian Emerging Equity Markets. Journal of Financial and Quantitative Analysis. Vol. 40. pp. 1-27

Rjoub, H., Türsoy, T., dan Günsel, N. 2009. The Effects of Macroeconomic Factors on Stock Returns: Istanbul Stock Market. Studies in Economics and Finance. Vol. 26. pp. 36-45.

Salm, Christian dan Schuppli, M. 2010. Positive Feedback Trading in Stock Index Future. International Review of Financial Analysis. Vol. 19. Pp. 313-322

Samarakoon, L, P. 2009. The Relation Between Trades of Domestic And Foreign Investors and Stock Returns in Sri Lanka. Journal of International Financial Markets, Institutions and Money, Vol 19, 850-861.

Sapian, R, Z, Z dan Auzairy, N, A. 2015. Foreign Equity Flows and Market Return Linkages: Evidence of Malaysian Stock Market. Global Business Review. Vol 16, 1-14. 
Sevil, Güven. 2012. Foreign Investors and Noise Trade in Istanbul Stock Exchange. International Journal of Business and Social Science.

Simorangkir, Iskandar dan Suseno. 2004. Sistem dan Kebijakan Nilai Tukar. Seri Kebanksentralan No.12. Jakarta: Pusat Pendidikan dan Studi Kebanksentralan Bank Indonesia (PPSK BI).

Sukirno, Sadono. 2002. Pengantar Teori Makroekonomi. Jakarta: PT. Raja Grafindo Persada.

Syamala, S.R., Chauhan, Y., dan Wadhwa, K. 2014. Institutional Investors and Stock Liquidity: Evidence from Indian Stock Market. Global Business Review, Vol 15, 461-476.

Tandelilin, Eduardus. 2010. Portofolio dan Investasi Teori dan Aplikasi. Edisi Pertama, Yogyakarta: Kanisius.

Tim Studi Bapepam-LK. 2008. Analisis Hubungan Kointegrasi dan Kausalitas serta Hubungan Dinamis antara Aliran Modal Asing, Perubahan Nilai Tukar dan Pergerakan IHSG di Pasar Modal Indonesia. Bapepam-LK.

Udegbunam, R.I dan Oaikhenan, H.E. 2012. Interest Rate Risk of Stock Prices in Nigeria: Empirical Test of The Duration and Convexity Model. Journal of Emerging Market Finance. Vol. 11.

Ülkü, N. dan Weber, E. 2013. Identifying the Interaction Between Stock Market Returns and Trading Flows of Investor Types: Looking into The Day Using Daily Data. Journal of Banking and Finance. Vol. 37. pp. 2733-2749.

Ülkü, N., dan İkizlerli, D. 2015. The Interaction Between Foreigners Trading and Emerging Stock Returns: Evidence from Turkey. Emerging Markets Review, Vol 13, 381-409.

Vo, X.V. 2017. Trading of Foreign Investors and Stock Returns in an Emerging Market: Evidence from Vietnam. International Review of Financial Analysis.

Wang, Jianxin. 2007. Foreign Equity Trading and Emerging Market Volatility: Evidence from Indonesia and Thailand. Journal of Development Economics. Vol 84. pp. 798-811

Widarjono, Agus. 2017. Ekonometrika: Pengantar dan Aplikasi. Yogyakarta: UPP STIM YKPN. 